glucose; the thiomalate, thiocaproic acid, thioglycerol, thioglycoanilide and thiosulphate derivatives of $\mathrm{Au}(\mathrm{I})$ are inactive. Evidently a specific in vivo glucose receptor is destroyed by the presence of gold. Such studies may improve our understanding of the nature of obesity.

\section{Conclusion}

There is widespread interest in the effect of gold compounds on biological systems, especially since, with the aid of modern physical techniques, we can begin to map out the activity of gold in molecular terms. We can often locate gold inside cells and in some cases pin-point its binding sites on macromolecules such as enzymes. As this knowledge increases, so the design of new gold compounds, either as metallodrugs or as heavy-atom labels, will undoubtedly improve.

\section{Acknowledgements}

I am very grateful to Dr B. Vernon-Roberts and $\mathrm{Mr} \mathrm{J}$. L. Doré of the London Hospital Medical College, Dr C. Danpure of the Clinical Research Centre, Northwick Park, Dr P. D'Arcy Hart of the National Institute for Medical Research and Dr L. B. Hunt of Johnson Matthey \& Co Ltd for discussion and for supplying material as indicated in the text.

\section{References}

1 R. M. Talipov and Sh. Khatamov, Uzb. Geol.Zh., 1974, 18, 23-7

2 R. M. Talipov and Sh. Khatamov, Uzb. Geol. Zh., 1973, 17, 26-31

3 E. D. Korobushkina, A. S. Chernyak and G. G. Mineer, Mikrobiologiya, 1974, 43, 49-54

4 Metabolism, Pharmacology and Therapeutic Uses of Gold Compounds by W. D. Block and K. Van Goor, Am. Lect. Series 282 , published by C. C. Thomas, Springfield, Illinois, U.S.A., 1954

5 R. Koch, Deutsche Med. Wchnschr., 1890, 16, 756

6 P. D'Arcy Hart, Brit. Med. J., 1946, 2, 805 and 809

7 K. Landé, Muknch. Med. Wchschr., 1927, 74, 1132

8 ERC Trial, Ann. Rheum. Dis., 1961, 20, 315

9 T. J. Constable, A. P. Crockson, R. A. Crockson and B. McConkey, The Lancet, 1975, May 24, 1176-79

10 B. M. Sutton, E. McGusty, D. T. Walz and M. J. Di Martino, F. Med. Chem., 1972, 15, 1095-98

11 D. T. Walz, M. J. Di Martino, B. Sutton and A. Misher, F. Pharm. Exp. Ther., 1972, 181, 292-297
12 J. Weinstock, B. M. Sutton, G. Y. Kuo, D. T. Walz and M. J. Dí Martino, f. Med. Chem., 1974, 17, 139-140

13 P. J. Sadler, Structure and Bonding, in the press

14 A. A. Isab, P. J. Sadler, C. J. Danpure, D. A. Fyfe and P. A. Charlwood, manuscript in preparation.

$15 \mathrm{~J}$. L. Doré, Thesis for Diplomate Fellowship to the Institute of Medical Laboratory Sciences, London, 1974

16 R. M. Burnett, G. D. Darling, D. S. Kendall, M. E. LcQuesne, S. G. Mayhew, W. W. Smith and M. L. Ludwig, f. Biol. Chem., 1974, 249, 4383-92

17 S. Lindskog, L. E. Henderson, K, K. Kannan, A. Liljas, P. O. Nyman and B. Strandberg, The Enzymes, Ed. by P. D. Boyer, Vol. V, 587-665, published by Academic Press, London, 1971

18 H. Eklund, B. Nordström, E. Zeppezauer, G. Söderlund, I. Ohlsson, T. Boieve, B-O. Söderberg, O. Tapia, C-I. Bränden and A. Akeson, F. Mol. Biol., 1976, 102, 25-59

19 F. R. Salemme, S. T. Freer, N. H. Xuong, R. A. Alden and J. Kraut, F. Biol. Chem., 1973, 248, 3910-21

20 C. C. F. Blake, Adv. Prot. Chem., 1968, 28, 39

21 H. Scouloudi, Proc. Roy. Soc. Lond., 1960, A258, 181; M. M. Bluhm, G. Bodo, H. M. Dintzis and J. C. Kendrew, Proc. Roy. Soc. Lond., 1958, A246, 369

22 G. E. Schulz, K. Bjedermann, W. Kabsch and R. H. Schirmer, F. Mol. Biol., 1973, 80, 857-64

23 P. L. Wendell, T. N. Bryant and H. C. Watson, Nature New Biol., 1972, 240, 134-136

24 E. A. Padlan and W. E. Love, 7 , Biol. Chem., 1974, 249, 4067-78

25 M. J. Adams, D. J. Haas, B. A. Jeffery, A. McPherson, H. L. Mermall, M. G. Rossmann, R. W. Schevitz and A. J. Wonacott, F. Mol. Biol., 1969, 41, 159

26 B. C. Wang, C. S. Yoo and M. Sax, F. Mol. Biol., 1974, $87,505-508$

27 A. Tulinsky, N. V. Mani, C. N. Morimoto and R. L. Vandlen, Acta Cryst., 1973, A29, 1309-22

$28 \mathrm{M}$. Horisberger, J. Rosset and $\mathrm{H}$. Bauer, Experientia, $1975,31,1147$

29 G. Frens, Nature Phys. Sci., 1973, 241, 20-22

30 C. J. Meade, P. J. Lachman and S. Bremner, $\mathcal{F}_{\text {. Immunol., }}$ $1974,27,227$

31 C. K. S. Pillai and U. S. Nandi, Biopolymers., 1973, 11, 1431

32 D. W. Gibson, M. Beer and R. J. Barrnett, Biochemistry, $1971,10,3669-3679$

33 J. T. R. Fitzsimons, D. W. Gibson and R. J. Barrnett, 7. Histochem. Cytochem., 1970, 18, 673-4

34 C. Dragulescu, J. Heller, A. Maurer, S. Policec, V. Topeui, M. Csalci, S, Kirschner, S. Kravitz and R. Moraski, Inst. Coord. Chem. Conference, 1974, XVI, 1.9

35 J. Mayer and N. B. Marshall, Nature, 1956, 178, 1399-40 36 R.J. Martin and P. Lamprey, Liffe Sci., 1974, 14, 1121-31

\title{
Gold Coated Glass for Solar Insulation
}

Several methods of reducing the effects of solar radiation in buildings are now avaitable, including the use of a gold film applied to the inner surface of the outside panes of windows. This gold coating allows part of the visible radiation to pass through while reflecting much of the infra-red. In a paper by Werner Klein of the Jenaer Glaswerk Schott und Genossen in Mainz, West Germany (Glass, 1976, $53,(3), 91-94)$, the special property of gold that makes it suitable for this purpose is described-its low emission coefficient for long-wave radiation. Thus gold coating emits less long-wave radiation to the inside of a room than the outside pane emits to the atmosphere. In addition, this property of gold results in a considerable improvement in thermal insulation in winter by a marked improvement in the coefficient of heat transfer.

The intensive reflection colour from gold-coated glass does, however, pose one problem to the architect. This has been largely overcome by the introduction of reflection-reducing interference layers to give blue-toviolet reflection colours that are architecturally attractive, while they increase substantially the amount of light transmitted in the yellow-to-green region. 